\title{
セシウム鉱物資源
}

\author{
松田亀 三*
}

\section{Cesium : it's mineral resources}

\section{By}

Kamezo MATSUDA

\section{I. 利用の状況}

\section{1． 金属の性質}

金属セシウムは銀白色，蠟の様に軟かい金属で 圧力を受けるとゴム状となり，1/2の容積に迄圧縮 される。アルカリ金属中最む反応性が大きく，水 に触れて爆跳し湿つた空気に接すれば自然着火す る。他のアルカリ金属と比べると諸性質沙第 1 表 の様になる1)。

第 1 表

\begin{tabular}{c|r|r|r|r|r|r}
\hline \hline 種名 & 原子量 & $\begin{array}{l}\text { 比重 } \\
\left(20^{\circ} \mathrm{C}\right)\end{array}$ & $\begin{array}{l}\text { 融点 } \\
\left({ }^{\circ} \mathrm{C}\right)\end{array}$ & $\begin{array}{l}\text { 沸点 } \\
\left({ }^{\circ} \mathrm{C}\right)\end{array}$ & $\begin{array}{l}\text { イオン } \\
\text { 化電厓 } \\
(\mathrm{V})\end{array}$ & $\begin{array}{l}\text { 半径 } \\
(\AA)\end{array}$ \\
\hline $\mathrm{Li}$ & 6.94 & 0.53 & 186.0 & 1336 & 5.39 & \\
$\mathrm{Na}$ & 22.99 & 0.97 & 97.5 & 883 & 5.14 & 0.98 \\
$\mathrm{~K}$ & 39.10 & 0.86 & 63.7 & 758 & 4.34 & 1.33 \\
$\mathrm{Rb}$ & 85.84 & 1.53 & 38.5 & 700 & 4.18 & 1.48 \\
$\mathrm{Cs}$ & 132.91 & 1.90 & 28.5 & 670 & 3.89 & 1.65
\end{tabular}

Cs に光を当てると自由電子が放出される光電 効果は, 既に30年も前から電子管に応用され，現 在では真空管, 増幅管, シンチレーション計数 管, 写真露光計, 光電管, 暗視野照準器（夜間監 視装置, Sniperscope）等にCs 塩類が用いられ， その消費は着実に伸びては居るが，日本の消費は 塩類として $5 \sim 6 \mathrm{Kg} /$ 月程度であり, 鉱石から金 属や塩類の抽出は行なわれて居ない。

上表から見ればアルカリ金属中 Cs は，イオン 半径最大, イオン化電圧最低, 熔融点最低, 原子 量最大等の性質があり，之の特質を生かす調查研

*国際鉱産コンサルタント。International Minerals Survey.
究が専ら行なわれて居るのがその現状である。

\section{2. 調査研究の状況}

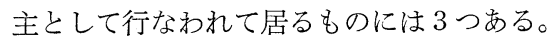

1) 熱電子発電器 (Thermoionic Generator)

Cs ガスを封入した真空管内でタングステン板を 加熱すると Cs から熱電子が放出され，電流が生 ビ得る。ソ聯邦では $\mathrm{kW}$ 級のものの開発に成功 したと伝えられる2)。

2) 電磁流体発電法 (Magneto Hydrodynamic Generation, 略称 MHD 発電) 此原理は既に 1831年 FARADAY により考案され，磁場閒に導電 体としての水銀を移動させて電流を検定し得る事 を示したが，現在より約20年前迄は全く顧みられ なかつた。近年 MHD 発電によれば熱エネルギ 一を直接電気エネルギーに変換可能であり, 従来 の迴転部分のある発電設備より沽かに高能率と考 えられるので1960年には米国でアルゴンプラズマ を用いて $10 \mathrm{~kW}$ の発電を数秒間得た ${ }^{32}$ 。 日本政 府も昭和41年度より 7 年間に 156 億円の研究開発 費を投入する事になつたと云う4。

1970年，ソ聯邦はモスクワに $8 \mathrm{MW}$ の火力と MHD の複合発電所の運転を始め, 米国も50 MW のものの建設を計画 ${ }^{5)}$ ， カナダ政府も $1500 \mathrm{MW}$ のものの研究開発に 3 億弗の支出を許可したと報 ぜられた6)。MHD 発電の作働流体としては種々 のイオン化燃焼ガスから成る導電性プラズマを磁 場に直交して超音速で流し，生じた電流を採りだ すのであるが, 其燃焼ガスの熱電離を促進する為 に, イオン化電圧の最も低い Cs を, 炭酸塩で 1 〜 $2 \%$ 混入(Seeding, 種蒔き)する。600 MW の 
発電には初回装入量として 100 万 lb. (500 s.t), 操 業には700万 $\mathrm{lb} . / \mathrm{Yr}\left(3500\right.$ s.t)の $\mathrm{Cs}_{2} \mathrm{CO}_{3}$ が必要と 云われる7)。猶 1958 年カナダで $\mathrm{Cs}$ 鉱床が発見さ れたが，ソ聯邦は 67 71年に亘り鉱石 $450 \mathrm{t}$ の買 付を行ない，更に増量の見込で之の大部分は MHD 発電に使用される筈と云われる8)。

3) イオンロケットエンデン Cs 蒸気が加 熱した多孔質板から拡散して正荷電イオンとな り，その高温高圧のガス気流が更に電場間に於て 加速されると時速 48 万 $\mathrm{km}$ の高速を示す事とな り，之をノズルから噴射させると，強烈な推進力 を展開できる。

ソ聯邦では，1964年 3 人乗りの宇宙船に之を用 い, Voskhod 号では, 1 回の航行に Cs 数 $\mathrm{t}$ を 消費すると謂われる9)。米国では航空宇宙局 (N. A.S.A.)が 1968年実験衛星一Dに搭載した ${ }^{10)}$ 。

\section{3. 需要見込}

Cs の生産は米国では 1961 年から発表を禁止さ れて居るが，まだ戦略備蓄物資には大つて居な い。1961年の数字を基礎にして, 米国鉱山局が68 年及び 2000 年の米国に於けるCs の需要見込を行 なつた数字は第 2 表の様である11)。

第 2 表

\begin{tabular}{|c|c|c|c|c|}
\hline \multirow{2}{*}{ 需 } & \multirow{2}{*}{ 要 } & \multirow{2}{*}{$\begin{array}{c}\text { 1968年 } \\
\text { 需要量 } \\
\text { (lb.) }\end{array}$} & \multicolumn{2}{|c|}{ 2000年需要量予想 (lb.) } \\
\hline & & & 大 & 小 \\
\hline 製 & 薬 & 300 & 500 & 200 \\
\hline 電 & 子 & 700 & 3,500 & 1,500 \\
\hline 研 究 開 & 発 & 4,500 & 30,000 & 8,000 \\
\hline 其 & 他 & 500 & 3,000 & 1,000 \\
\hline 計 & & 6,000 & 37,000 & 10,700 \\
\hline
\end{tabular}

米国では嘗ってポラックス石 ${ }^{12} 50 \mathrm{t}$ 程度を採掘 した事もあるが，現在は採掘終了状態であり，ポ ラックス石はロデシアから, 塩類は主として西独 から輸入して居た。米国鉱山局の報告では1968年 もポラックス石の自由世界年産は, $20 \mathrm{t}$ 程度で今 後の研究開発の動向により著しい増産が見込める として居たが，モザンビックでは1969 70年に其 数倍を産出して居り ${ }^{13)}$, 意外に早く需要の増大が 期待されるのではないか。その予想では 2,000 年 に於て甚だ需要が伸びた時には, 各国の需要量む
同程度に伸びるとして 1968 年度推定の 6 倍程度 68,000 lb (34 s.t)を考えて居る。

\section{II. セシウム含有鉱物}

Cs は花崗岩質ペグマタイト, 特に晚期熱水性 複合ペグマタイト中の加里を含む鉱物中に, Rb と共に濃集する。火成岩の平均含有量は 1 p.p.m 以下に過ぎないが14), 花崗岩では 115 p.p.m に達 するものがある15)。水成岩形成の過程では粘土に 吸着される事が多く, 水成岩平均は 4 p.p.m とな つて居る。Strunzによると Cs 含有鉣物は 5 種が あげてある。

1. ポラックス石(後出)

2. ローディザイト(Rhodizite)

等軸, $\mathrm{H}=8 \quad \mathrm{G}=3.4$

色彩, 白一灰, $\mathrm{N}=1.694$

成分, $(\mathrm{Cs}, \mathrm{K}, \mathrm{Rb}) \mathrm{Al}_{4} \mathrm{Be}_{4}\left[\mathrm{~B}_{11} \mathrm{O}_{26}\right.$

$\left.(\mathrm{OH})_{2}\right], \mathrm{Cs}_{2} \mathrm{O}=7.54 \%$

3. $\mathrm{CsBF}_{4}$ 人工鉱物 斜方

4. $\mathrm{Cs}\left[\mathrm{FeSi}_{2} \mathrm{O}_{6}\right]$ 人工鉱物 等軸

5. Cs-carnotite 人工鉱物 単斜 成分

$\mathrm{Cs}_{2}\left[\mathrm{UO}_{2} \mathrm{I}_{2} \mathrm{O}_{8}\right]$

現在ポラックス石だけの採掘は行なわれて居な いが，自由世界で鉱石として扱われるのはポラッ クス石だけと思われて居た。併し昨年ソビエトロ シアでは, アルタイ山地のアルカリペグマタイト からセシウムクプレッカイトと云う新鉱物を発見 し，ポラックス石に次ぐ Cs 鉱石になり得るもの と発表した ${ }^{17)}$ 。之はクプレッカイト (Kup letskite, $\left.(\mathrm{KNa})_{3}(\mathrm{MnFe})_{7}(\mathrm{TiNb})_{2}\left[\mathrm{Si}_{8}(\mathrm{O} \cdot \mathrm{OH})_{31}\right]\right)$ で $\mathrm{Cs}_{2} \mathrm{O}$ $11.6 \%$ を含み, 三斜系, 星葉石一蛭石状, 黄金褐 色, 䢃開完全, $\mathrm{H}=4, \mathrm{G}=3.68$, であると云う。

其他 Cs を含む鉱物としては Cs 鉱物を含むぺ グマタイトから産する鱗雲母 $\left(\mathrm{Cs}_{2} \mathrm{O} 0.08 \sim 0.7\right.$ $\%)$, 白雲母 $(0.06 \sim 0.2 \%)$, 黒雲母 $(0.3 \sim 3.5 \%)$, 緑柱石 $(0.5 \sim 7.5 \%)$, 微斜長石 $(0.11 \sim 0.14 \%)$,

曹長石 $(-0.28 \%)$ 等がある。

海水中では苦汁集中し, スタッスフルト産カ 一ナライト $\left(\mathrm{K} \cdot \mathrm{Mg} \cdot \mathrm{Cl}_{3} \cdot 3 \mathrm{H}_{2} \mathrm{O}\right)$ に $\mathrm{CsCl} 0.8 \%{ }^{18)}$, 又山口県福川塩田産海水には Cs として10 $2 \times$ $10^{-3} \mathrm{mg} / \mathrm{l}$ 含まれる報告がある ${ }^{19) 。 ~}$

猶鈗石ではないが，嘗つて米国でロデシア産鱗 
雲母から $\mathrm{Li}$ を抽出し，その残渣注 ALKARB (Alkali carbonate の商品名) と称され, $\mathrm{Cs}_{2} \mathrm{CO}_{3}$ $2 \sim 3 \%$ を含むので米国では, Cs の貴重な資源 と見做されたが，ポラックス石の出現により寧ろ $\mathrm{Rb}$ 原料 $\left(\mathrm{Rb}_{2} \mathrm{CO}_{3} 20 \sim 25 \%\right)$ として重視され20), 現在は使用されて居ない。

\section{III. ポラックス石の性質}

本鉱物は石英に酷似することで有名であり，産 出極めて稀と思われて居たが，石英と区別困難の 儘放置されて居り，それほど稀産ではなくなつて 来た。

\section{1. 物理性}

結晶形 : 等軸晶系に属するが結晶形を示すもの は殆んどない。ペグマタイトの最終期である Cs 交代作用の結果として, 塊状, 又電気石, 默輝 石, 葉長石, アンブリゴン石等の仮晶学為す例が ある。

䢃開 : 殆んど認められない。

光沢色彩 : 石英に酷似するが，無色硝子状のむ のと, 不透明で白色一弱帯紅白色, 長石状のもの と亦る。長石状のものは白色緑柱石, 加里長石, 葉長石，アンブリゴン石等との区別が必要であ る。又ポラックス石は, 風化すると $\mathrm{K}_{2} \mathrm{O}$ の大部 分は残るが其他のアルカリは流亡して， $\mathrm{Cs}_{2} \mathrm{O} 9$
\%を含む軟質, 白色,カオリン状の物質に変る ${ }^{21 。}$ 風化面を細かに見れば石英とは区別出来る等であ るが，坑内ではまず不可能であろう。

硬さ：モース硬度 6.5 となつて居るが大部分の ものは $5 \sim 6$ の間にある。

比重 : $\mathrm{G}=2.68 \sim 2.98$ で $\mathrm{Cs}_{2} \mathrm{O}$ の含有量の高い もの程比重が大である。

屈折率 : 鏡下での屈折率は硝子状のものも, 長 石状不透明白色のものも, 共に等方質で, 石英長 石の共生体を含む事が多く, N=1.507 1.527間 江変化し, 含有水分が増加すれば屈折率核減少す る。此屈折率ならば曹長石 $(\alpha=1.527)$ 上り多少低 く, 杉油 $(\mathrm{N}=1.516)$ よりは少し高いと云う事に なる。勿論クローブ油, バルサムよりは低い。

紫外線：紫外線を照射すると白色又はピンク色 の螢光を発するものがあり，米国メーン州のもの は長波 (3650 ̊) で，淡オレンヂ色を出すが，短波 (2537 ̊) では反応がないと云う22)。決定的な試験 方法ではない。

熱発光 : 全く研究が無い。

$\mathrm{X}$ 線: 粉末回折法が最もよく使われる。単位格 子の大きさは $13.63 \AA \AA$ 13.65 13.68 ̊̊である23)。

\section{2. 化学性}

冷塩酸には徐々に溶解して粉状珪酸を分離す る。雌色を分光器に通すと $4355 \AA ̊$ と $4593 \AA ̊$ の輝青

第 3 表

\begin{tabular}{|c|c|c|c|c|c|c|c|c|c|c|c|c|c|}
\hline 産 & $\mathrm{N}$ & G & $\mathrm{SiO}_{2}$ & $\mathrm{Al}_{2} \mathrm{O}_{3}$ & $\mathrm{Cs}_{2} \mathrm{O}$ & $\mathrm{Rb}_{2} \mathrm{O}$ & $\mathrm{Li}_{2} \mathrm{O}$ & $\mathrm{K}_{2} \mathrm{O}$ & $\mathrm{Na}_{2} \mathrm{O}$ & $\mathrm{H}_{2} \mathrm{O}$ & 計 & & \\
\hline $\begin{array}{c}\text { カ } \\
\text { マント名(1) }\end{array}$ & 1.520 & 2.88 & 44.7 & 14.9 & 36.2 & 0.10 & 0.05 & 0.06 & 1.74 & 1.44 & 100.09 & & \\
\hline $\begin{array}{l}\text { スェーデン (2) } \\
\text { バルトレスク }\end{array}$ & & 2.917 & 46.28 & 16.71 & 30.77 & 1.60 & 0.25 & 0.51 & 1.87 & 1.80 & 100.08 & $\begin{array}{l}\mathrm{P}_{2} \mathrm{O}_{5} \\
0.25\end{array}$ & $\begin{array}{c}F \\
0.03\end{array}$ \\
\hline $\begin{array}{c}\text { 南 西 阿(3) } \\
\text { カルビブ }\end{array}$ & 1.517 & 2.865 & 45.7 & 17.2 & 30.2 & $\begin{array}{l}+\mathrm{K}_{2} \mathrm{O} \\
1.3\end{array}$ & & & 2.8 & 2.66 & 99.86 & & \\
\hline $\begin{array}{c}\text { ロデシア (4) } \\
\text { ビ キ タ }\end{array}$ & & & 47.09 & 17.41 & 26.60 & 0.91 & 0.41 & 2.00 & 3.02 & 2.20 & 99.94 & $\begin{array}{l}\mathrm{P}_{2} \mathrm{O}_{5} \\
0.30\end{array}$ & \\
\hline 米メーン国(5) & 1.507 & 2.68 & & & 24.48 & & & & & 3.80 & & & \\
\hline 米苂コタ州 & & & 47.88 & 17.96 & 23.46 & 1.06 & 0.12 & 1.06 & 3.58 & 3.82 & $|99.44|$ & $\begin{array}{l}\mathrm{CaO} \\
1.04\end{array}$ & $\begin{array}{l}\mathrm{MgO} \\
0.38\end{array}$ \\
\hline
\end{tabular}

(1) E. H. Nickel (1961), Dept. Min. Tech. Surv. Can. T. B. 20, June.

(2) P. Quensel (1956), Arkiv. Min. Geol 2(2), p, 9-125.

(3) H. J. NeL (1944), Amer, Min. p. 443-51.

(4) D. G. CoOper (1964), Geol. of Some Ore Deposits of So, Afr. Vol. 2, p. 460.

(5) W. E. Richmond, F. A. GonYer (1938), Amer, Min. p. 783-9.

(6) G. M. SchWARZ(1930), Econ. Geol p. 275-84. 
線の確認が出来る。

ポラックス石の表面を弗化水素酸で侵し, 之に $\mathrm{KBiI}_{4}$ の試薬を 1 滴落せば $\mathrm{Cs}_{3} \mathrm{Bi}_{2} \mathrm{I}_{9}$ の緋色の沈 澱を生ずる24)。此反応は薄片上の染色にも用いら れるが, 弗酸は危険であり塩酸処理が適当である。 低品位鉱の場合には鏡下に $\mathrm{Cs}_{3} \mathrm{Bi}_{2} \mathrm{I}_{9}$ の結晶の確 認を行う25)。

上記反応は弗酸の代りに弗化アンモンで鉝物粉 末を熔融しても同様な反応が見られる。

化学成分, 無水物としての $\mathrm{CsO} \cdot \mathrm{A}_{2} \mathrm{O}_{3} \cdot 5 \mathrm{SiO}_{2}$ $\left(\mathrm{Cs}_{2} \mathrm{O}=45 \%\right)$ は天然には産せず，天然産は何れ も $\mathrm{Na}_{2} \mathrm{O}, \mathrm{H}_{2} \mathrm{O}$ 等を含み, $\mathrm{H}_{2} \mathrm{O}(\mathrm{Cs} \cdot \mathrm{Na})_{2} \mathrm{O} \cdot \mathrm{Al}_{2} \mathrm{O}_{3}$ - $5 \mathrm{SiO}_{2}$ として $\mathrm{Cs}: \mathrm{Na}=5: 2$ の場合は $\mathrm{Cs}_{2} \mathrm{O}=$ $31.4 \%$ となる。STRUNZ $\left.{ }^{26}\right)$ はその化学式を [(Cs・ $\mathrm{Na})\left(\mathrm{AlSi}_{2} \mathrm{O}_{6}\right) \mathrm{H}_{2} \mathrm{O}_{1}$ 】として居る。

分析例を第 3 表に挙げる。

之を要するにX線粉末回折法が利用できれば問 題はないが，湿式定性反忘と鏡下の性質で充分決 定できる筈である。

\section{IV. 含ポラックス石ペグマタイト}

現在セシウムの需要も微々たるもので, 従つて ポラックス石だけを採掘する鉣山はない。有名産
地は何れもタンタライト, リシウム鉱, 緑柱石等 を採掘し，その副産物としてポラックス石を産出 する。ソ聯邦ではポラックス石の大鉱床存在の発 表はないが，曹灰長石一金雲母脈をも鉱床に含め

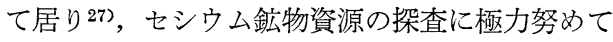
居る様に見られる。

之等の鉱床を通覧するに，大規模のものは $2 つ$ の著しい特徴がある。1つは何れも先寒武系中の 花崗岩に伴うぺグマタイトで旧期（ソ聯邦及びロ デシア ${ }^{37)}$ )のものも新期(南西阿28)及びモザンビッ ク 29)）のものもある。次いで, ペグマタイトは何 れも累帯配列をする複合型のもので, リシウム鉱 物の默輝石，特に鱗雲母安伴い，带青色片状一糖 晶状曹長石（クリーブランド石）を伴う特徴があ る。此のペグマタイトの貫入した急泠相の部分の 雲母の微量成分の検討はペグマタイト中にポラッ クス石の伏在を推定するのには極めて有力な手段 で30)，GORDIYENKO はペグマタイト中の微斜長

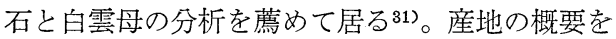
次に紹介する。

\section{1. カナダ, マニトバ州 Bernic Lake} 位置 : ウィニペグ市北東 $110 \mathrm{~km}$.

沿革 : 探鉱目標が決らない為に開山迄約 40 年経

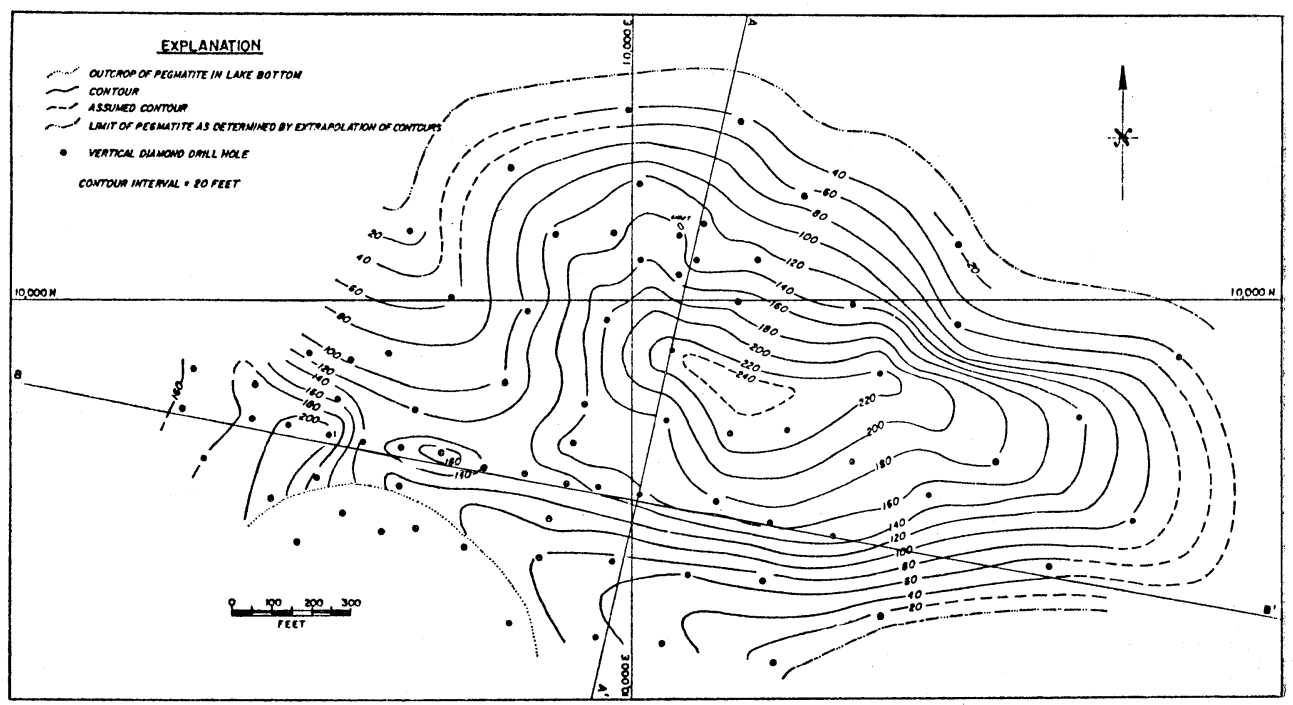

Isopach map of the Montgary Pegmatite, Bernic Lake, Manitoba.

第 1 図 試錐分布図(等層厚線図) C.M. WRIGHT(1963)による 


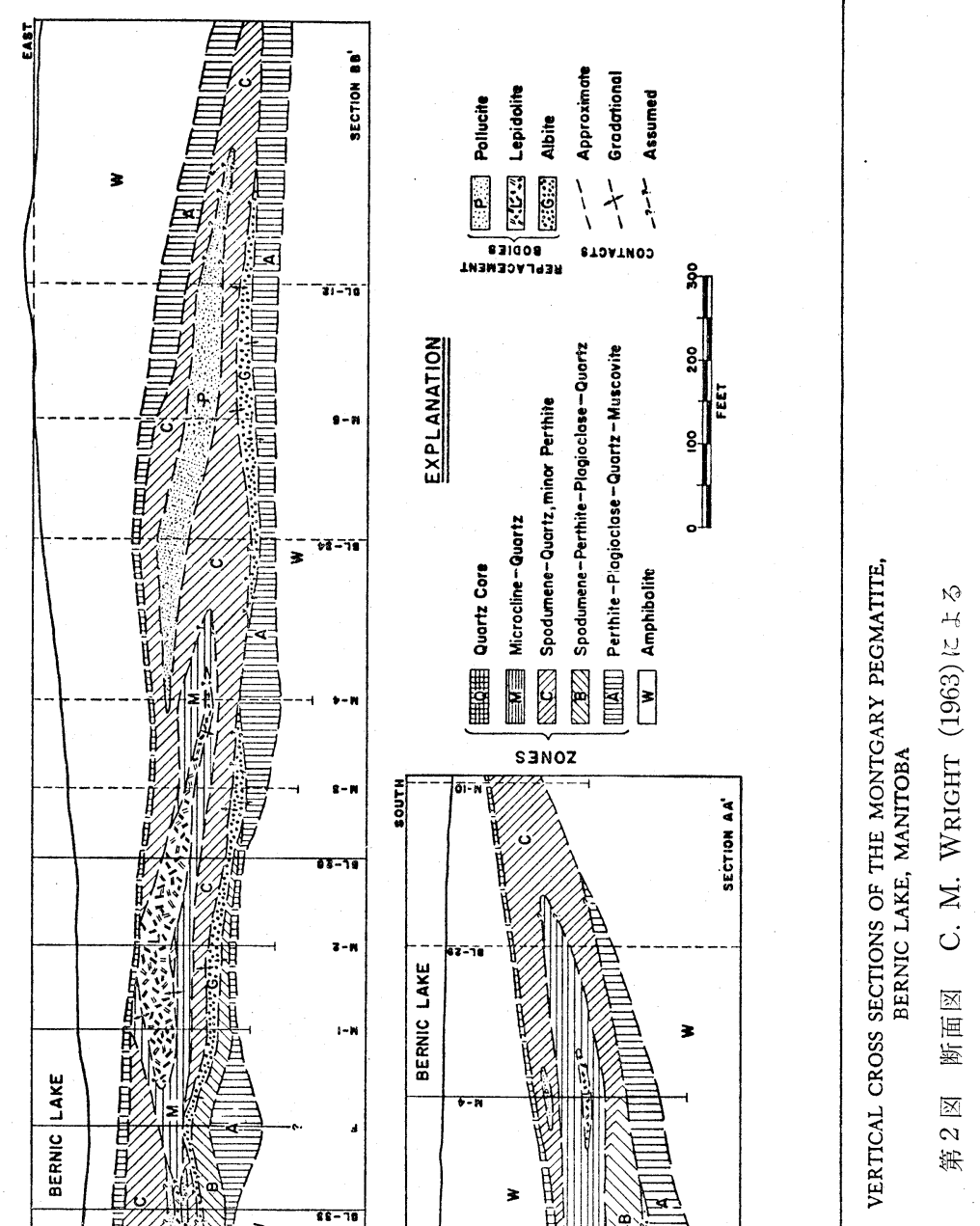




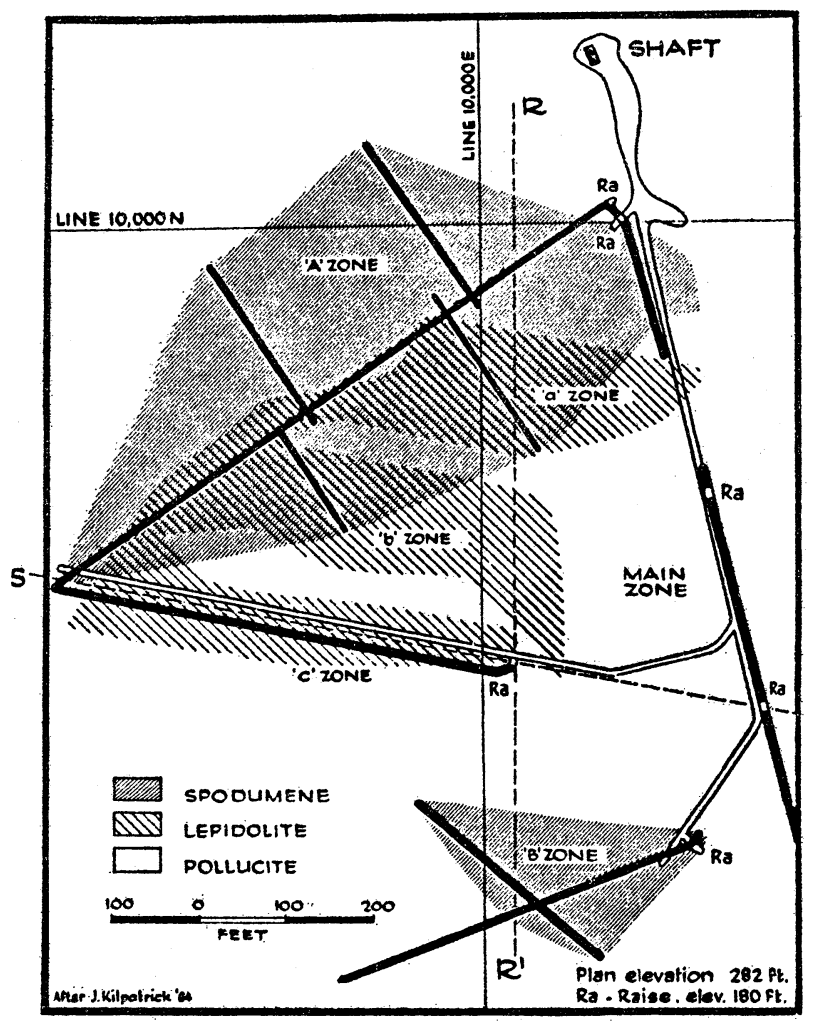

- Schematic Plan of the Economic Mineral Assémblages.

第 3 図 坑道探釷図 A. C. A. Howe \& J. C. ROWNTREE（1969）による

過し，探鉱費だけで100 150万弗を費した。 1929年 錫石調査の為堅坑掘下げ。 1930年 試錐 1 本で繁輝石を確認。

1954 57年 CHEMALLOY 社, 試錐44本, 26000 呎, 竪坑掘下げ 308 呎地並迄。

1957年後半に AMAX 社が探鉱オプション, 1958年試 錐21本6693呎,同社技師 HUTCHINSON がポラックス石帯を確認したがオプションは放 棄。

1959 61年 CHEMALLOY 社 坑内探鉱, 竪坑掘 下げ339吹地並迄, 水平坑道, 7,680呎, 坑内試錐 182 本, 猶ポラックス石及び緑柱石帯確認の為の地表 試錐19本6,584呎を実施したが，62年休山。

1967年 GOLDFIELD CORP. N.Y. 社の援助の 下に探鉱再開。

1969年 タンタル鉱山会社を設立しタンタライイ
卜鉱 $500 \mathrm{t} / \mathrm{d}$ の選鉱場を設け操業に入つた。生産 開始迄の総起業費は 930 万弗, 開発に踏み切つた 時の鉣量は 190 万 $\mathrm{t}, \mathrm{Ta}_{2} \mathrm{O}_{5}, 0.23 \%$ であた ${ }^{32) 。}$

鉱床 : 此地方は氷河堆積物と湖水だけで露頭は 殆んど無いので試錐で鉱体の形を推定した。(第 1

図試錐分布図) ${ }^{33)}$

母岩は先寒武系片麻岩, 角閃岩で之等を貫く花 崗岩質ペグマタイトが鉣床をなし，その過半は湖 底下に在る。ペグマタイトは横臥円盤状, 走向略 東西, 傾斜北方 $15^{\circ}$, その大きさは直径 $450 \mathrm{~m}$, 厚さ最大 $85 \mathrm{~m}$ である。母岩の斜長石角閃岩は, ペグマタイトに接する部分だけが電気石化作用を 蒙り, 之に接するペグマタイトの急冷相の部分は 石英斜長石の集合体になつて居る。

此のペグマタイトは複合型で, 急冷部から岩体 内部に向つては結晶粗大となり，ペルト石で長さ 
4 呎，黝輝石，アンブリゴン石で長さ 3 呎に達す る。ペグマタイト内部は次の 5 帯に分類される (第 2 図参照 $)^{34)}$ 。

1）ペルト石一石英一斜長石 白雲母 内壁部

2）墨輝石一ペルト石一斜長石一石英 中間帯

3）默煇石一石英

4) 微斜長石一石英 II

5）石英 "I 内核部

内核部と中間帯の間にレンズ状に含まれる半花 崗岩質クリーブランド石は, 糖晶状の集合体で厚 さ $13 \mathrm{~m}$ に及ぶ指示相をなし, 之に近く産する細 粒㴛密のポラックス石帯及び鱗雲母帯は, HUTCHINSON によると交代性成因と考えられると云 う。猶 HOWE, ROWNTREE によれば, 鱗雲母中 には $\mathrm{Ga}$ 成分が一様に分布し，0.1〜0.2\% Ga を示すと云う事実は, 鈗物種名の決定迄は行なつ てないが，甚だ注目に值する。随伴鉱物として は，貫入部周辺のみに見られる緑柱石，又上記ク リーブランド石岩体の周辺に伴うものとしてタン タライト, チンワルド雲母(ラベンダー色), 錫石 (黄一ピンク色), 柘榴石, 電気石等がある。ポラ ックス石鉱体は延長 $180 \mathrm{~m}$, 最大厚さ $13 \mathrm{~m}$ のレ
ンズ状をなし，他に小鉱体が 2 つる。ポラック ス石だけの単一組成で, 粒径 $1 \mathrm{~cm}$ 以下のものの 集合体である。

鉱量 : 試錐数本だけで推定した鉱量は坑道探鉱 してからのものとは品位に於て多少の相違があり (第 3 図 坑道探鉣図参照)。当初は埋蔵鉱量とし て30万 $\mathrm{t} \mathrm{Cs}_{2} \mathrm{O} 20.4 \%{ }^{35)}$ と発表されたが，最近の 発表では $293,863 \mathrm{t}$, 品位 $\mathrm{Cs}_{2} \mathrm{O} 23.67 \%$ となつて 居る。最近現鈗体の下部 150 呎に試錐で，更に新 しいペグマタイトを捕捉したので36) 上記の数字は 増加の見込である。

\section{2. ロデシア，マショナランド州，Bikita ${ }^{37)}$}

位置 : ソルスベリ市の南微東 $170 \mathrm{~km}$, Fort Victoria の東 $50 \mathrm{~km}$ である。

沿革 : 1911年 Bikita 錫鉱地帯に現地残留性錫 石，タンタライトの存在が明かになり，鉱区設定 が行なわれた。1916年〜1950年間に錫石，200t， タンタライト $100 \mathrm{t}$ を産出したが, 此間に緑柱石, 葉長石等が発見され採掘対象が之に移つた。1952 年 SELECTION TRUST 社が之に興味を持ち探鉱 契約し, BIKITA MINERALS を設立, 之に AMAX 社と AM. POTASH CHEMICAL 社が加わり, 20

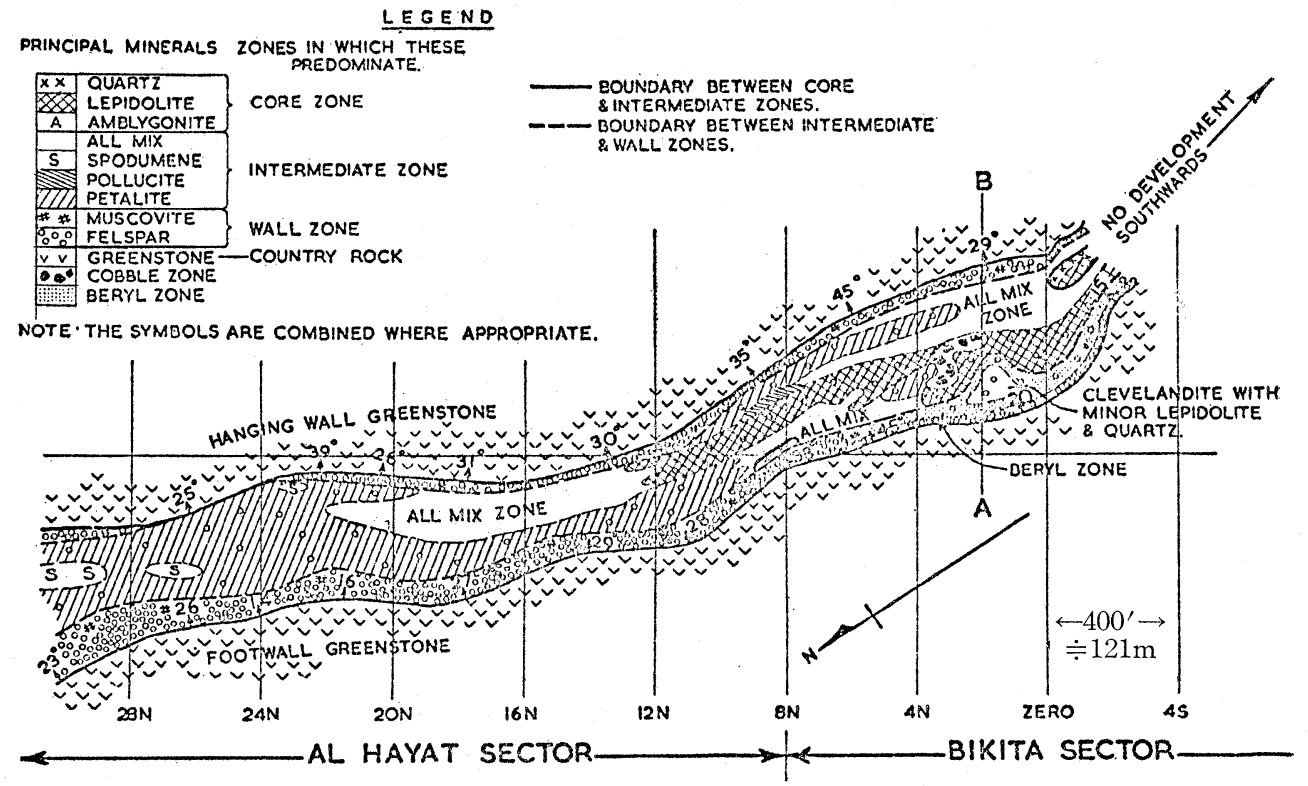

Geology on 900-ft level horizon, Al Hayat and Bikita sectors.

第 4 図ビキタ鉱山 900 呎地並地質図 R. SYMONS (1961)による。 


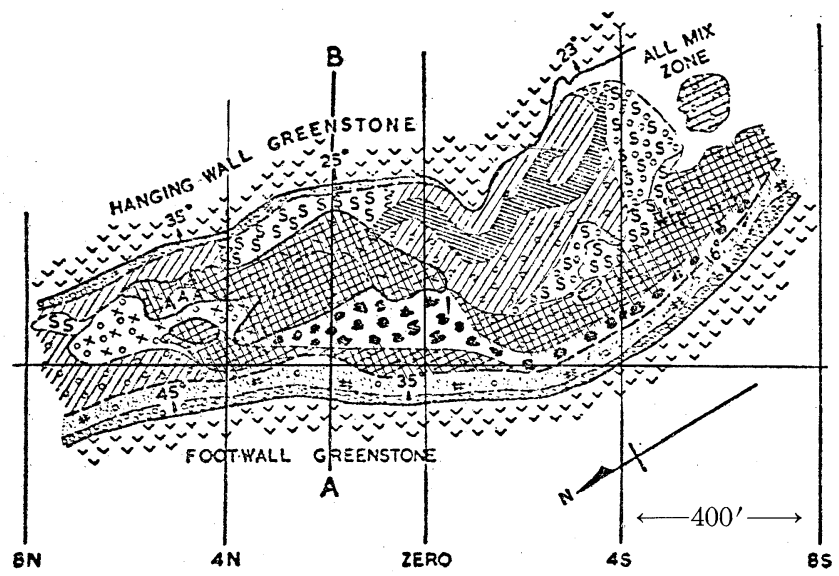

Geology on 1000-ft level horizon, Bikita sector.

第 5 図 1000 吹地並地犋図 R. SYMONS（1961）による

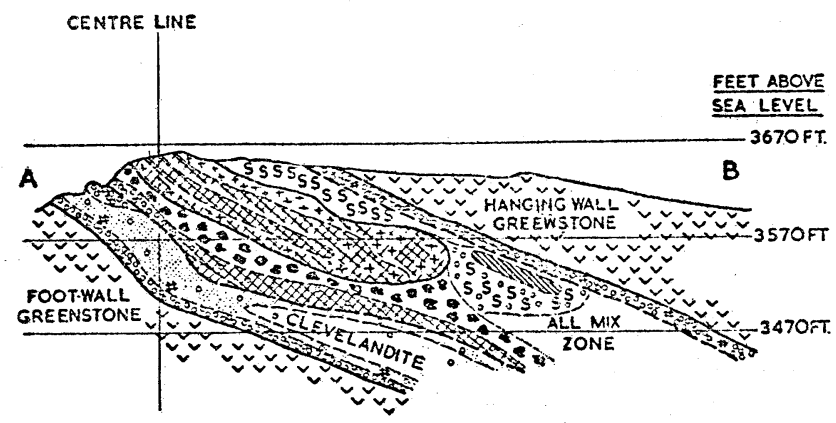

-Section $(A-B)$ through Bikita sector on section line $2 N$.

第 6 図AB 線断面図 R. SYMONS（1961）による。

カ月間の探鉱の結果，鱗雲母鉱の採掘だけで投資 可能乙考えて, 開発に踏切つた。契約終了後は 3 地並で14,877吹の坑道探鉱を行ない，5000 t/週の 選鉱設備を以つて出鉱を始めた。此閒ポラックス 石の産出は，1953年からで数 $\mathrm{t} / \mathrm{Yr}$ であつたが， 1962年 $20 \mathrm{t}, 1964$ 年 $26 \mathrm{t}\left(\mathrm{Cs}_{2} \mathrm{O} 27 \%\right)$ の産出が報 ぜられたが38)，1966年からは産出が無い。1959 65年間には $160 \mathrm{t}$ を産した ${ }^{399}$ 。

鉱床 : 先寒武系基盤岩類のメンバーである緑色 岩類を貫く花崗岩質ペグマタイト（絶対年代26億 5000万年，始生代）が鉱床となつて居り，複合累 帯構造を示して居る。その走向略南北, 傾斜東方 $14^{\circ} \sim 45^{\circ}$ の板状体で探鉱終了部分は全長 $8 \mathrm{~km}$ の 内延長 $1600 \mathrm{~m}$ で, 厚さ $30 \sim 65 \mathrm{~m}$, 北半の $\mathrm{Al}$
Hayat 区は葉長石を採掘し, 南半は鱗雲母を採掘 する(第 $4 ， 5 ， 6$ 図参照)。

母岩の緑色岩注変質塩基性噴出岩で, 地表では 緑色粘土に変化し, ペグマタイトの貫入による変 質作用は上盤側だけに見られ, 電気石, 黒雲母等 が生じて居る。ペグマタイトその物は地下 $20 \mathrm{~m}$ 迄は風化䨖爛するが, 累帯構造の内核部である塊 状鱗雲母帯は風化に耐え, 残存して屹立した急崖 となる。累帯構造は内壁部, 中間帯, 内核部とに 分れ, 中間帯では葉長石の長さ $2 \mathrm{~m}$, 厚さ $30 \mathrm{~cm}$ に達するものを産する。此のペグマタイト中に産 する鉱物は30種に達するが，採掘して居るものは 葉長石，默輝石，アンブリゴン石，ユークリプト 石, 緑柱石，タンタライト，マイクロライト，錫 
石で，随伴鉱物にはビキタ石，シンプソン石，ユ 一クセン石，ヘルバイト，燐灰石，黄玉等があ る。

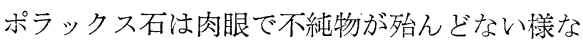
ものでも, $\mathrm{SiO}_{2} 40 \%$ 内外学含む事があり，粗鉱 品位は $\mathrm{Cs}_{2} \mathrm{O}$ 6 30\%に変化する。

鉱量 : 米国鉱山局の発表によると ${ }^{40)}$, 鉱量 15 万 $\mathrm{t}$ と発表して居るが品位は未詳である。

\section{3. 南西アフリカ Karibib 及び Omaruru 地} 方

位置 : ウィンドフック市の北西 $100 \mathrm{~km}$ 周辺で ある。ポラックス石の認められた Helicon 鉱床 は, Karibib の東南東 $21 \mathrm{~km}$, Okongawa Ost 農 園の北東端に在る ${ }^{41)}$ 。

沿革: 当地方は古くから知られたペグマタイト 地帯で Erongo の錫鉱は1929年から，Karibibの リシウム鉱は1932年から開発され，ポラックス石 の存在は1944年に報告されたが1966年からはその 産出は無い42)。

鉱床 : 当地区は先寒武系の褶曲した苦灰岩，玨 岩等の変成岩類を貫く花崗岩質ペグマタイトが多 数産する部分で, 米国地質調査所の CAMERON 技師は白雲母，緑柱石の調查を目的として，約 60 本のペグマタイトを踏査して居る43)。

当所のペグマタイトは新旧 2 期の花崗岩の内, 新期のものに伴い，何れも累帯構造を示し，幅30 $\mathrm{cm}$ 以下の急冷相より内部に向い, 内壁部, 中䦎帯, 内核部が見られる。その大きさは延長 $40 \sim 450 \mathrm{~m}$, 幅 $2 \sim 180 \mathrm{~m}$ で著しく大きいものではない。主な 採掘対象である緑柱石 は白一緑一黄金黄色を示 し，之の採掘で賄えなければ他の随伴鉱物では到 底採算迄には至らないと云われる。主な随伴鉣物 は葉長石，アンブリゴン石，タンタライト，錫 石, マイクロライト, 自然蒼鉛, 電気石 (紅色), 黄玉(青色)等があり，内核部の石英帯を囲んで鱗 雲母を産する。

ポラックス石は Helicon ペグマタイト試掘地 で，石英内核部と上盤アンブリゴン石帯との中間 に延長 $10 \mathrm{~m}$, 幅 $3 \mathrm{~m}$ で露出し, 数立方米の掘跡 が在る。

鉱量 : 米国鉱山局の発表によると ${ }^{44)}$ 鉱量 5 万 $\mathrm{t}$ (品位不詳)を挙げて居るが Helicon のものだけ
では無理である。

4. モザンビック，ザンベジア州, Alto Ligonha 地方

位置 : 海港の Beira，及び Lumbo の中間の Mocuba 部落から，その北東 $180 \mathrm{~km} の$ Alto Ligonha 部落を中心とするペグマタイト地帯で ある。

沿岸 : 詳しい沿革はわからないが 6 鉱山でタン タライト, 緑柱石等を採掘し45)ていたり, 中止し

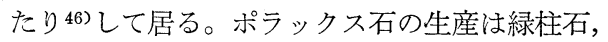
鱗雲母の生産に伴い1961年 $6 \mathrm{t}, 1969$ 年 $200 \mathrm{t}, 1970$ 年100t と報告されて居る40)。

鉱床 : 先寒武系後期の花崗岩, 花崗片麻岩, 変 成片岩類が基盤をなし，之を貫いて多数のペグマ タイトがある48)。何れも複合ペグマタイトで，鱗 雲母, アンブリゴン石，タンタライト，緑柱石， 蒼鉛，雲母等が稼行されるが，花崗岩中のペグマ タイトには有用鉱物を欠き, 変成片岩類中のペグ マタイトには有用鉱物を産すると云 5。その大 きさは延長 200 1000 m, 幅 10２50 m である。 HUTCHINSON の調査当時にはポラックス石は報 告されてはなかつたが 1961年に始めて $6 \mathrm{t}$ を輸出 し，副産物としての生産が見られる様になつた。 だがその賦存状態に就いての報告はない。

鉱量 : 発表されたものはない。

\section{5. 其の他の諸国}

スエーデン : 北部スエーデン Varuträsk のも のは先寒武系を貫く複合型默輝石ペグマタイト で，Cs 交代作用により葉長石を交代してポラッ クス石が産出し，鉱化作用の最末期にクリーブラ ンド石が出来て居る49)。ペグマタイトの大きさは 走向延長 $60 \sim 400 \mathrm{~m}$, 幅最大 $100 \mathrm{~m}$ で数本存在す る。主な Cs 鉱体は，棈円形乃至不規則形塊状を なし，ポラックス石の集合体は延長最大 $10 \mathrm{~m}$ 程 度，幅 $0.5 \sim 8 \mathrm{~m}$ で 10 個見当賦存する様であ る50)。鋐量品位は未詳だが大きいものではない。

アメリカ：4州にポラックス石の産地があるが 略採掘終了と見てよいのであろう。

日本 : 福岡市今宿長垂には戦時中にリシウム鉱 を採掘した跡があり，その碰中から桑野範行氏に より本邦初産のポラックス石が報告された ${ }^{51)}$ 。そ の決定には，粉末 X線曲折法と赤外線吸収スペク 
278

トルを使つてある。

地質は後期白亜紀の花崗岩と之を貫くペグマタ イトから成り, ペグマタイトは35 36本在るが長 垂トンネル西口に近いものだけがリシウム鉱を含 む。昭和15年から $\mathrm{Li}_{2} \mathrm{O} 2 \%$ の鉣石 200 を出鉣し て採掘終了したと云う52)。ペグマタイトに産する 鉱物としては鱗雲母, アンゴリゴン石, 葉長石, 緑柱石(白一バラ紅色), クリーブランド石等が見 られるが，鉱量品位は未詳である。

\section{V. 鉱石の処理工程}

\section{1. 採 鉱}

ペグマタイトの産状により露天掘りなり, 坑内 掘りによるのであるが粗鉱は数回の手選で硑を除 去して売鉣される。

\section{2. 選 鉱}

現在は手選塊鉱で商品になるが将来はぺグマタ イト粉鉱からポラックス石の回収も当然考えるべ きで，米国鉱山局では既に1962年草試験を行なつ た ${ }^{53)}$ 。此実験はメーン州産のものを用い，逆浮選 法で雲母, 默輝石, 長石等を浮上させて除去し, ポラックス石を沈鉣に濃集して回収する。 -100 目に砕き硫酸酸性とし, 弗酸でポラックス石の浮 上を抑制し，カチオン試薬を用いて，上記鉱物を 浮上させる。元鉱品位 Cs $8 \%$ のものら精鉱品 位 $20 \%$ ののを実収率 Cs 87\%で得て居り，原鉱 中の $\mathrm{Rb}$ の $82 \%$ は浮上雲母中に濃集して居る模様 である。

\section{3. 抽 出}

ポラックス石から Cs の抽出法としては主なも のに酸リーチング, 塩化焙焼又は揮発法, 直接還 元法等があるが，最も生産コストの高いのが直接 還元法, 又安いのは酸リーチングの内でも塩酸に よるものであると云ら54)。以下に概要を紹介す る。

酸リーチング 第 2 次大戦中, 理化学研究所 が福島県飯坂水晶山の黒雲母から, 硫酸リーチン グで光電材料のクロム酸セシウムを回収した。弗 化臭素酸による方法もある55)。塩酸抽出の場合は $8.8 \mathrm{~N}-\mathrm{HCL}$ で $100^{\circ} \mathrm{C} ， 6$ 時間の抽出を行い，脱 珪酸後, 精製する。

塩化焙焼, 揮発法 精鉱に石灰石, 塩化カル
亀三

シウムを混合し， $900^{\circ} \mathrm{C}$ に焙焼して层焼物を水中 で抽出する。又 $1300^{\circ} \mathrm{C}$ に加熱し 揮発昇華物を精 製する。前者の実収率は $96 \%$, 後者では $98 \%$ に達 する。

直接還元法 精鉱に還元剤を加えて, 直接還 元をする。各種還元剤の内, $\mathrm{Ca}$ が再蒸溜の必要 がなく最も好成績を挙げた。ポラックス石の Cs 含量に対し，12倍の $\mathrm{Ca}$ を加えて団鉱としアルゴ ン気圈中で 3 時間, $700^{\circ} \mathrm{C}$ に加熱する。鉣石中の Cs の $92 \%$ が揮発し， $72 \%$ が凝集，凝集部の品位 は90.1\%であつた。上記の試験で，Cs $10 \%$ の鉱 石を $3500 \mathrm{t} / \mathrm{Yr}$ 処理するとして, 鉣石価格 $20 \$ / \mathrm{t}$ な らば, Cs の直接生産費は $\mathrm{Mg}$ による 直接還元法 で最も高く $3 \$ 80 / \mathrm{Cslb}$, 塩酸リーチング法による

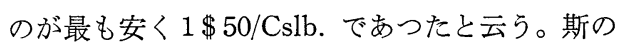
様にして得られた金属 Cs は其取扱い, 貯蔵, 運 搬には細心の注意が必要で，パイレックス硝子又 ステンレス容器中に真空, 又はアルゴン気中に密 封して収め, 衝撃防止の方法を充分に講じて市場 に出される。

\section{VI. 価 格}

抽出の技術が発達して, 鉱石需要があり, 鉱石 価格が決るのであるが, 現在の様に僅かな需要で は相場とか国際価格の様なものは無い。結局各鉱 山が需要家との間に交渉によつて決める值段と云 う訳である。ポラックス石は石英と区別困難なの で，品位を一定にして売鉱するには充分な試料分 析と数回の手選鉣が必要で, 其為鈗石価格も割高 となる。近年の鉣石価格を見ると次の様である。

Bikita 産（1964 年), $26 \mathrm{t}, \mathrm{Cs}_{2} \mathrm{O} 27 \%$, 山元 FOB $2272 £=88 £ / t=244 \$ / t^{56)}$, Bernic Lake 産(1960年), $425 \$ / \mathrm{s.t} \mathrm{t}^{57}$ (1971年), 品位 $\mathrm{Cs}_{2} \mathrm{O} 20 \%$ 保証, 山元 FOB $13 \$ 50 / 20 \mathrm{lbs}$ (one unit) $=270 \$ /$ s.t t $^{58}$

但し1970年，ソビエトロシア向けは $\mathrm{Cs}_{2} \mathrm{O} 20$ \%ベースで $305 \$ / \mathrm{t} \quad \mathrm{Cs}_{2} \mathrm{O} \quad 1 \%$ 増毎に $5 \$ / \mathrm{t}$ を 加えるので $\mathrm{Cs}_{2} \mathrm{O} 27 \%$ ではで $340 \$ / \mathrm{t}$ あつた 59)。

Mozam bique 産(1970年), 品位未詳だが英国 向け $140 \mathrm{t}$ を10,000ミで売鉱した ${ }^{59) 。 71.42 ~}$ $£ / t=178 \$ 55 / \mathrm{t}$ 
ヨーロッパ，相場は一応建つて居るが名目許り

で, $\mathrm{Cs}_{2} \mathrm{O} 24 \%$ 以上, $\mathrm{FOB}$ 価格, 4.773 $£ /$ unit $=11 \$ 93 /$ unit $(£=2.50 \$$ とする) で, $\mathrm{Cs}_{2} \mathrm{O} 24 \%$ な $114.552 £ /$ s.t, 又は 286.32 \$/s.t となつて居る58)。

Cs 塩類価格も鉱石同様 で市中価格は無い。米 国と日本の輸入した日のの一部を見ると次の様で ある。

米国(1968年) $\mathrm{CsCl}$ (西独) $1160 \mathrm{lb} .=45,000 \$$ $=38.8 \$ / 1 b^{60)}=86.20 \$ / \mathrm{kg}$

日本(1968年) $\mathrm{Cs}_{2} \mathrm{CO}_{3}$ (西独, Cs $85 \%$ ) $5 \sim 60$, 000円/kg61)

金属 Cs 滇純度により標準種 Cs $99.5 \%$ 以上 と高純度種 $99.9 \%$ 以上とに分れ, その細かい仕様 は省略するが，1961年頃は，2〜4\$/gr であつた のが最近は $100 \$ \sim 375 \$ / 1 b$ 即ち $0.22 \$ / g r 〜 0$. $79 \$ / g r$ となつて居る60)。

\section{要 旨}

熱, 光のエネルギーを, 直接電気エネルギーに变 換できるセシウムの需要は, 今後の調査研究の成 果に俟つ処が甚だ大きい。其結果によつては20年 以内に, 或いは現在の世界消費の 6 倍, $34 \mathrm{t}$ に達 するかも知れないと謂われる。現在の消費は微々 たるもので, 従つてその原鉱石たるポラック石だ けを採掘する鉱山は無く，副産物として回収され て居るに過ぎないが，1968年の世界生産量20t/年 が 100t/年を越す様になつて来たのは。研究開発 の結果に著しく発展が見られる事を物語るもので あろら。セシウム鉱源の探査に甚だ力を入れて居 るのはソ聯邦で, 自由世界では考え難い低品位鉱 をも処理の対象にして居る様である。ポラックス 石はペグマタイト中にのみ産し，大規模の鉱床は 先寒武系内に限られ，カナダ Bernic Lake の鉱 床は世界最大のものと云える。その随伴鉱物には 特徴があり, リシア鉱物特に鱗雲母, 帯青色クリ ーブランド石を必ず伴う。従つて此等の随伴鉱物 を産するもので，石英があれば，ポラックス石と しての再検が必要であり，更に発見の可能性があ る。先ず既存ペグマタイトの随伴鉱物の検討から 始める事が，新鉱床捕捉の端緒となるであろう。

\section{文献及び注}

1) R. Sisselman(1971): Min. Eng. No. 8, p. 74-6 を補足した。沸点は, 理化学 辞典, 無機化学ハンドブック (p. 326) で は $760^{\circ} \mathrm{C}$, Phillipsborn, U.S.B.M. Bull. では $705^{\circ} \mathrm{C}$, Gmelin, Merck, 新版地学辞 典では $670^{\circ} \mathrm{C}$ とつて居るが兹では $\mathrm{Gme}$ lin 等の数字を挙げてある。

2) R. SisSELMAN (1971) 前出.

3) 高橋秀穂, 吹田徳雄 (1964) : エネルギー 変換論, ラティス, p. 153.

4) 玉置环磨, 荻原宏康 (1967)：MHD発電, 総合図書, p. 24.

5) Min. Ann. Rev. 1971, p. 93.

6) N. Miner (1971) : Dec. 2, p. 1264.

7) N. Miner (1971) : 前出.

8) R. SisselmaN (1971): 前出.

9) Min. Ann. Rev. 1971, p. 93

10) R. Sisselman (1971): 前出.

11) R. A. HeindL (1970) : U.S.B.M. Bull No. 650, p. 527-34.

12) Pollucite (Cs, Na) ( $\left.\mathrm{Al} \mathrm{Si} . \mathrm{O}_{6}\right) \mathrm{H}_{2} \mathrm{O}_{1}$, $\mathrm{Cs}_{2} \mathrm{O}=30 \sim 36 \%$ 現在唯 1 の $\mathrm{Cs}$ 鉱石と見 做される。

13) W. Mining (1971) : June, 25, p. 135.

14) E. L. Horstman(1957) : Geohim. Cosmochin Acta Vol. 12, No. 1-2, p. 128.

15) R. Greenwood (1960) : Min. Eng. No. 5, p. $482-3$.

16) H. Strunz (1970) : Min. Tabellen, 5 Auflage.

17) A. F. IEFIMOV \& Others (1971): Dokl, Akad, Nauk, S.S.S.R, No. 6, p. 1394-7.

18）松田俊治 (1958)：鉱物誌, Vol. 3, No. 6 , p. 523.

19）原田保男 (1943) : 日, 化, 会誌, Vol. 64, No. 8, p. 1049-53.

20) D. E. EILERTTSEN (1965) : U.S.B.M. Bull, No. 630, p. 205-9.

21) P. Quensel (1938) : Geol, För, Förh, Bd. 60, p. 612-34.

22) S. Gleason (1960) : Ultraviolet Guide to Minerals. D. Van Nostrand. N.Y.

23) B. M. Shaub \& B. J. Schenk (1954): Am. Min. No. 7-8, p. 661-4 及び後出. 51) 桑野氏 (1970) 文献参照.

24) K. F. G. Fosking (1961) : Min. Mag。 May p. 280-2. 
25) K. C. DEAN \& I. L. NiChOlS (1960) : U.S.B.M. R. I. No. 5675.

26) H. STRUNZ (1970) : 前出.

27) L. N. Ovchinnikov \& N. A. SoloDov (1971) : Sov. Geol No. 7, p. 1530.

28) E. N. CAmeron (1955): Tr. Proc. Geol. Soc, So, Afr., Vol. 58, p. 4570.

29) 森永茂(1969)：アフリカ印度新金属資 源買付促進調查報告，新金属協会，p. 46.

30) R. GREenwood (1960) : 前出. R. B. BHAPPU (1965): So, Afr, Min, Eng, Jnl, Oct. 8, p. 2342-4.

31) V. V. GORDIYENKO (1971) : Intern, Geol, Rev., Feb. p. 134-42.

32) R. Garlick (1969) : Can. Min. Jnl, Nov. p. 47-51.

33) C. M. Wright (1963) : Bull, Geol. Soc. Am. July. p. 919-46.

34) R. W. Hutchinson (1959) : Econ, Geol. No. 8, p. 1525-42. C. M. WRIGHT. (1963) : 前出. A. C. A. HowE \& J. C. Rowntree (1967) : Can. Min. Met. Bull. Feb. p. 207-12.

35) A. C. A. Howe \& J. C. Rowntree (1967)：前出.

36) N. Miner (1972) : Feb. 25, p. 143-4.

37) R. Symons (1961) : Bull. Inst. Min. Met. Dec. p. 129-72.

38) Metal Bull. (1965) : Spt. 14, p. 25. 工業レアメタル (1968) : No. 38, p. 712.

39) Mining Ann. Rev. 1971, p. 93.

40) U.S.B.M. (1965) : Bull. No. 630, 前出.
U. S. B. M (1965) : Bull.

41) C. Roering \& T. W. Gevers (1964) : "The Geology of Some Ore Deposits in So. Afr." Vol. 2, p. 484. C. Roering (1966) : Econ, Geol. No. 6, p. 1064-98.

42) Mining Ann. Rev. 1971, p. 93.

43) E. N. Cameron (1955) : Tr. Proc. Geol. Soc. So. Afr. Vol. 58, p. 45-70.

44) U.S.B.M (1965) : Bull. No. 630, 前出.

45）村岡 誠(1961)：鉱山地質, No. 45-46 号, p. 199-200.

46) 森永 茂 $(1969)$ : 前出.

47) W. Mining, (1971) : Jun. 25, p. 135.

48) R. W. Hutchinson \& R. J. Claus (1956) : Econ, Geol No. 8, p. 757-80.

49) P. Quensel (1966) : Econ, Geol., No. 6, p. 1069-70.

50) P. Quensel (1956) : Arkiv, Min, Geol., 2(2), p. 9-125.

51）桑野範之(1970)：地学研究, No. 11-12, p. 416-21.

52）木下亀城(1961)：九州地方鉱床誌，朝倉 書店.

53) K. C. DEAN \& L. C. Nichols (1962) : U.S.B.M, R. I No. 5940.

54) K. C. Dean \& Zothers (1966) : Jnl. Metals, Nov., p. 1198-1202.

55) R. Sisselman (1971): 前出.

56) Metal Bulletin (1965) : 前出.

57) N. Miner (1960) : April 11, p. 804.

58) N. Miner (1972) : Jan 20, p. 54.

59) Min, Ann, Rev. 1971, p. 93.

60) U.S.B.M (1970) Bull No. 650, 前出.

61）工業レアメタル(1968)：No. 38，前出. 